\title{
Biophysical Survey of the Hinatuan Enchanted River Underwater Cave System (HERUCS) and its Connecting River, Surigao del Sur, Southern Philippines
}

\author{
Ethel C. Wagas ${ }^{1}$, Dave Anthony Valles ${ }^{1}$, Cyril Taguba ${ }^{1}$, Dominic \\ Franco C. Belleza', Alex Santos ${ }^{2}$, Bernil Gastardo², Terence Paul \\ U. Dacles ${ }^{3}$, Annie G. Diola ${ }^{1}$ and Danilo T. Dy ${ }^{1}$
}

${ }^{1}$ Department of Biology, University of San Carlos, Cebu City, Philippines

${ }^{2}$ Filipino Cave Divers, Barangay Pajac, Maribago, Lapu-lapu City, Cebu, Philippines

${ }^{3}$ Deutsche Gesellschaft für Internationale Zusammenarbeit (GIZ)

ABSTRACT

A rapid survey inside the Hinatuan Enchanted River Underwater Cave System (HERUCS) and its connecting river was done to gather baseline data on the biophysical aspects of the cave and river ecosystem. It involved collection of water samples, sediments and macrofauna. Water samples were analyzed for the following parameters, namely: nitrates, phosphates, turbidity, $\mathrm{BOD}, \mathrm{pH}$, alkalinity, conductivity and total coliform. Sediment samples were analyzed for total organic matter and grain size. A listing of macrofauna found within the length of the established sampling station was also collected, photo-documented and identified. Water from inside the cave have a $\mathrm{pH}$ range of $7.35-7.39$, a BOD of $1.67-4.00$ $\mathrm{mg} / \mathrm{L}$, a 16 ppt salinity (at cave entrance), and, nitrate and phosphate values of 0.32 $-0.44 \mathrm{mg} / \mathrm{L}$ and $0.10-0.52 \mathrm{mg} / \mathrm{L}$, respectively. The mean total coliform count of the water sample from the upstream sampling site was 1,700 MPN/100 ml. There were 5 organisms belonging to 4 families recorded from inside the cave while 43 organisms belonging to 9 families were collected from its connecting river. Majority of the macrofauna samples collected were marine to brackish-water species and can be considered accidentals. Although there were no stygobites caught, the possibility of finding new species is high considering the depth of the cave and its many unexplored chambers. Further explorations are highly recommended with the use of mixed gas (i.e., Nitrox) for longer bottom time and more thorough sampling.

Keywords: macrofauna, biophysical monitoring, rapid resource assessment, underwater cave conservation and management

\section{INTRODUCTION}

Underwater cave systems are one of the least studied ecosystems in the world. "Wet" caves present a unique challenge to scientific study because they are largely hidden from view. These caves and their features exist in an environment with no 
natural light and contain a myriad of physical and psychological obstacles (Kambesis, 2007). Entrance to underwater caves can only be done through a specialized type of SCUBA diving, which requires advanced technical skills and knowledge. Sampling in such hostile environments is very limited and dangerous as dive time is restricted; entry or exits to caves are often difficult and divers are constantly at risk of nitrogen narcosis and other deep diving hazards. Although studying underwater cave environments are extremely challenging, it is nonetheless important because they constitute a naturally fragmented habitat that can act as refuge or ecological islands and are one of the most fragile ecosystems on earth (Chevaldonne and Lejeusene, 2003). Many troglobitic species (obligate cavernicoles) are capable of living in smaller ranges and are thus, considered very susceptible to changes in its environment (Culver et al., 2000). Despite their sensitivity to disturbance, cave ecosystems are still poorly understood (Wynne and Pleytez, 2005).

Biophysical investigations in most, if not all underwater caves in the Philippines are barely done mainly because of their inaccessibility and the dangers of entering such hostile environments. One such site is the Hinatuan Enchanted River Underwater Cave System (HERUCS), a fully submerged cave system located in Hinatuan, Surigao del Sur, Southern Philippines (Fig. 1). The cave opening is 27 meters below the head of a small river that connects directly to the sea. The area, more popularly known as the Hinatuan Enchanted River, is famous for its clear, turquoise waters and receives as many as 800-1000 visitors a day (especially on weekends). Over the past six years, the park area has been extensively developed. Concrete infrastructures such as cottages and tables, cemented walkways and stairs that lead down to the riverbank are existing. A small docking area for outrigger boats is also found 100 meters downstream of the river. Threatened by development, this natural heritage calls for a conservation plan, which is particularly important for "wet" caves found in close proximity to coastal areas where the average global population is estimated to be three times more concentrated (Small and Nichols, 2003). There is the need to evaluate the effects of high intensity use and balance this with effective conservation strategies. Thus, research in underwater caves is not only important for academic reasons, but more so, for establishing management baselines and for providing input into interpretive programs (Poulson, 1976). The potential to discover new species is high. This paper documents the first biophysical survey undertaken inside the Hinatuan Enchanted River Underwater Cave and its river system from March 19-26, 2015.

\section{MATERIALS AND METHODS}

\section{Sampling Protocols}

Three sampling stations were established inside the cave area to sample for water, sediment and invertebrate macrofauna. The entrance of the cave is at a depth of 27.30 meters. Station one was established about 5 meters (confirm depth with Bernil) from the entrance while stations 2 and 3 were located 24.6 meters (depth $=41.60 \mathrm{~m}$ ) and 67.2 meters (depth $=49.60 \mathrm{~m}$ ) from the cave entrance, respectively (Fig 2). A fourth (outside) station was also established to cover the upstream and midstream areas of the river. 


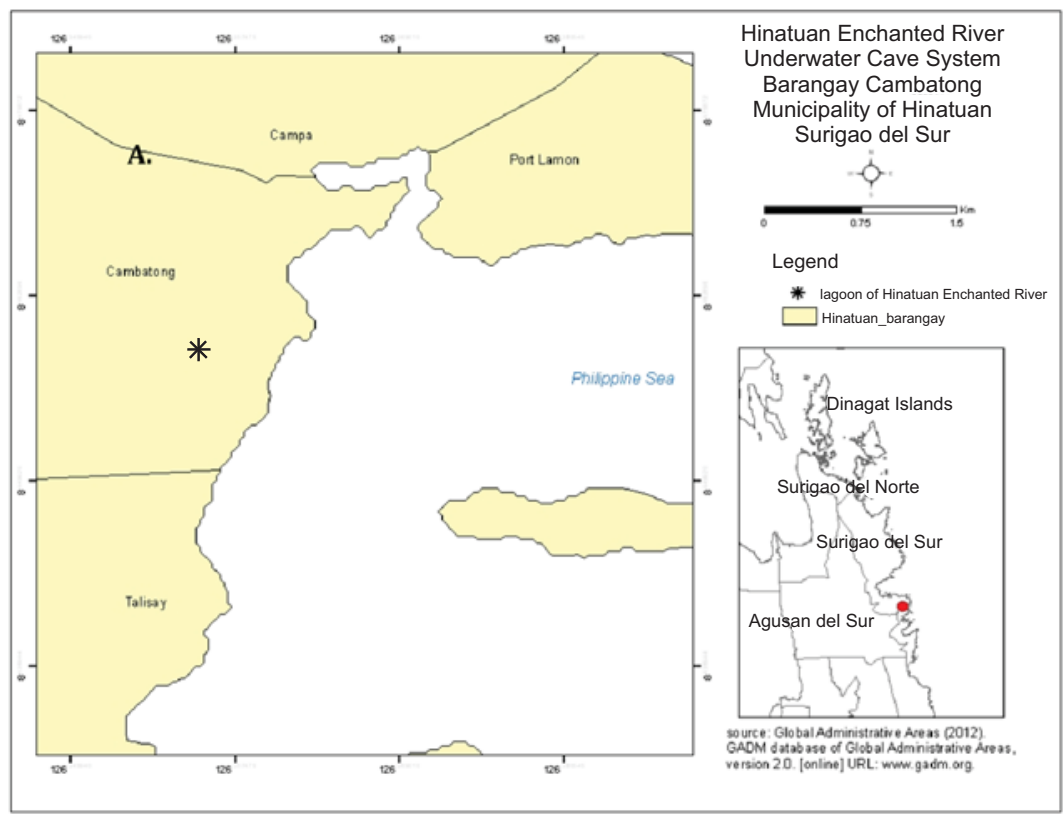

Figure 1. Map showing the location of the Hinatuan Enchanted River Underwater Cave System (HERUCS) in Surigao del Sur, Southern Philippines.

Water samples were obtained using 1-liter High-Density Polyethylene (HDPE) bottles in three replicates per established sampling station. Each replicate consist of two bottles (light and dark). Water samples were placed immediately inside a cooler with ice and transported to the laboratory in Cebu (Central Philippines) for analysis. The light bottle was processed for inorganic nutrient analysis while the dark bottle was used for determining the Biological Oxygen Demand (BOD). The collected water was analyzed for the following parameters using the corresponding standard methods (APHA, 1989): $\mathrm{pH}$ (electrometric), nitrate (colorimetric), phosphate (colorimetric), Biological Oxygen Demand or BOD (azide modification), conductivity (conductivity meter) turbidity (nephelometric test) and total coliform (multiple tube fermentation). It should be noted that the logistical limitation of the study area has required the researchers to transport the water samples to Cebu under chilled condition.

Sediment samples for total organic matter and for grain size measurements were obtained with PVC corers (1 inch in diameter; 4 inches in length), pressed vertically into the sediment. Three replicates per sampling station were brought to the laboratory for analysis. In the laboratory, total organic matter (TOM) of sediment samples were analyzed following the procedure by Argente et al. (2013). For grain size analysis, a small amount of the sediment was air-dried and viewed under the microscope. Digital images of the viewed sediments were taken and the ferret diameters of the grains in the image were measured using ImageJ Software (Janaka et al., 2012). The grain size distribution for each sediment sample was summarized and the mean grain size calculated.

Opportunistic sampling of invertebrate macrofauna was done throughout the length of the established guide line inside the underwater cave that spanned 67.2 meters from the cave opening to the inner chamber. All specimens found within 
the area were caught using hand nets or picked by hand. Samples were placed inside pre-labeled, re-sealable plastic bags and brought to a makeshift working station for processing.

Collection of representative samples of macrofauna (vertebrates and invertebrates) found upstream and midstream of the river directly connected to the underwater cave system was done in a similar manner as inside the cave. Fish traps, locally known as "panggal" were deployed in similar sites in the river. All organisms were photo-documented and fixed in formalin (standard concentration for the type of organism) or preserved with $80 \%$ ethyl alcohol for further taxonomic examination in the laboratory.
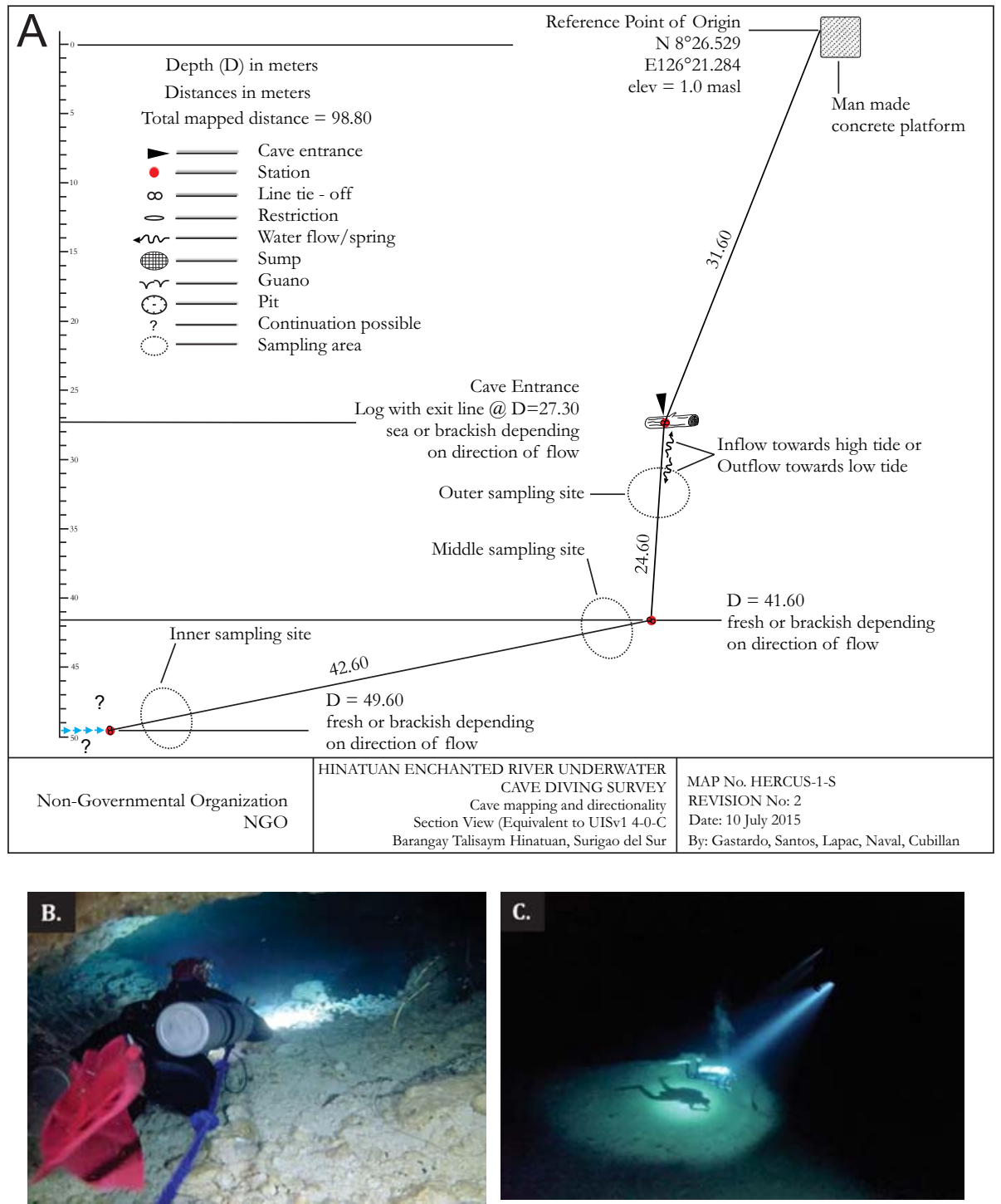

Figure 2. Map showing the (A.) section view of the Underwater Cave System as illustrated by Filipino Cave Divers (FCD) who dove inside the cave. (B.) Outer (C.) Middle and Inner stations were established inside the cave as reference for sampling. 


\section{RESULTS AND DISCUSSION}

Water inside HERUCS had phosphate concentrations of $0.10,0.52$ and 0.21 $\mathrm{mg} / \mathrm{L}$ for the outer, middle and inner chambers, respectively (Table 1). On the other hand, phosphate concentrations of sampled water in the upstream and midstream of the river were 0.33 and $2.03 \mathrm{mg} / \mathrm{L}$, respectively. Total coliform counts from the three stations inside HERUCS were 168, 263 and 213 $\mathrm{MPN} / 100 \mathrm{~mL}$ for outer, middle and inner stations, respectively. Coliform counts in the upstream and midstream of the river were high at 1,700 and $815 \mathrm{MPN} / 100 \mathrm{~mL}$ respectively.

The outer and middle sampling stations have relatively coarse sediments with sizes $8.1 \pm 4.5 \mathrm{~mm}$ (mean $\pm \mathrm{sd}, \mathrm{N}=3$ ) and $9.0 \pm 3.9 \mathrm{~mm}$, respectively. The sediments from the inner sampling station on the other hand, can be classified as fine sand with a ferret diameter of $0.2 \pm 0.1 \mathrm{~mm}$. On the average, the total organic matter of the sediments at HERUCS was relatively low (i.e., $1.4 \pm 0.1$ percent). Highest amount of total organic matter in the sediment was noted at the inner station $(2.5 \pm 0.7$ percent $)$ while the lowest was at the middle station $(0.9 \pm 0.2$ percent $)$.

Five marine macroinvertebrate species belonging to 4 families were collected inside HERUCS during the course of the survey (Table 2). These were the bivalves Isognomon (I. ephippium and Isognomon sp.); an unidentified polychaete worm (Sabellidae); an asterinid, Aquilonastra burtoni (Asterinidae) and an upside-down jellyfish, Cassiopaea andromeda (Cassiopeidae). Certain species of polychaete worms are considered to be common dwellers in underwater caves. In fact, tubicolous polychaetes are among the sessile animals that dominate the middle section of marine caves (Knittweis et al., 2015). The serpulid polychaetes are one of the main framework builders of biostalactites that form lamellar and/or fibrillar structures in cave walls (Guido et al., 2014, p. 265), as they are capable of tolerating low-oxygen conditions (Sageman et al., 1999, p. $547)$ like that in subterranean environments. On the other hand, the asterinid and jellyfish are common inhabitants in well-lighted environments exclusive cave dwellers, hence, are considered accidentals (sensu Iliffe, 2008).

Table 1. Values of water quality parameters at Hinatuan Enchanted River Underwater Cave System (HERUCS).

\begin{tabular}{|c|c|c|c|c|c|c|c|c|c|c|c|c|c|c|}
\hline Physico-Chemical & \multicolumn{3}{|c|}{$\begin{array}{c}\text { Outer } \\
\text { chamber }\end{array}$} & \multicolumn{2}{|c|}{$\begin{array}{c}\text { Middle } \\
\text { chamber }\end{array}$} & \multicolumn{3}{|c|}{$\begin{array}{c}\text { Inner } \\
\text { chamber }\end{array}$} & \multicolumn{3}{|c|}{$\begin{array}{c}\mathrm{Up} \\
\text { stream }\end{array}$} & \multicolumn{3}{|c|}{$\begin{array}{c}\text { Mid } \\
\text { stream }\end{array}$} \\
\hline Nitrate $(\mathrm{mg} / \mathrm{l})$ & 0.32 & \pm & 0.05 & 0.44 & \pm 0.15 & 0.35 & \pm & 0.22 & 0.38 & \pm & 0.00 & 0.48 & \pm & 0.04 \\
\hline Phosphate (mg/l) & 0.10 & \pm & 0.00 & 0.52 & \pm 0.55 & 0.21 & \pm & 0.13 & 0.33 & \pm & 0.16 & 2.03 & \pm & 0.54 \\
\hline Turbidity (NTU) & 0.13 & \pm & 0.12 & 1.35 & \pm 1.34 & 0.72 & \pm & 0.54 & 0.64 & \pm & 0.29 & 23.75 & \pm & 12.80 \\
\hline $\mathrm{BOD}(\mathrm{mg} / \mathrm{l})$ & 3 & \pm & 0.58 & 1.67 & \pm 0.58 & 4.00 & \pm & 4.36 & 2 & \pm & 0.00 & 6 & \pm & 0.71 \\
\hline $\mathrm{pH}$ & 7.39 & \pm & 0.06 & 7.36 & \pm 0.10 & 7.35 & \pm & 0.08 & 7.49 & \pm & 0.06 & 7.38 & \pm & 0.01 \\
\hline Tot. Alkalinity (mg CaCO3/1) & 195 & \pm & 8.5 & 197 & \pm 13.9 & 200 & \pm & 16.5 & 193 & \pm & 0.7 & 100 & \pm & 0.0 \\
\hline Conductivity $(\mu \mathrm{S} / \mathrm{cm})$ & 29 & \pm & 3.2 & 27 & \pm 7.4 & 26 & \pm & 5.4 & 26 & \pm & 0.3 & 221 & \pm & 2.8 \\
\hline \multicolumn{15}{|l|}{ Bacteriological } \\
\hline Total Coliform (MPN/100ml) & 168 & \pm & 146 & 263 & \pm 115 & 213 & \pm & 246 & 1700 & \pm & 849 & 815 & \pm & 827 \\
\hline
\end{tabular}

$\mathrm{n}=3$ for outer, middle and inner chambers

$\mathrm{n}=2$ for upstream and midstream 
Table 2. Listing of macrofauna collected inside and outside the Hinatuan Enchanted River Underwater Cave System.

\begin{tabular}{|c|c|c|c|}
\hline Species & Taxonomic groups & Sightings & Habitat \\
\hline Polychaete worm & Polychaeta: Sabellidae & 1 & $\begin{array}{l}\text { inner chamber at about } 48 \mathrm{~m} \text { depth } \\
\text { (only the tube was collected) }\end{array}$ \\
\hline Isognomon sp. & Pterioida: Isognomonidae & 2 & inner chamber at about $50 \mathrm{~m}$ depth \\
\hline $\begin{array}{l}\text { Isognomon ephippium } \\
\text { (Linnaeus, 1758) }\end{array}$ & Pterioida: Isognomonidae & 2 & middle chamber at about $39 \mathrm{~m}$ depth \\
\hline $\begin{array}{l}\text { Isognomon ephippium } \\
\text { (Linnaeus, 1758) }\end{array}$ & Pterioida: Isognomonidae & 5 & inner chamber at about $48 \mathrm{~m}$ depth \\
\hline $\begin{array}{l}\text { Cassiopea andromeda } \\
\text { (Forsskål, 1775) }\end{array}$ & Rhizostomeae: Cassiopeidae & 1 & $\begin{array}{l}\text { inner cave chamber (about } 49 \mathrm{~m} \text { ) } \\
\text { depth }\end{array}$ \\
\hline Asterina sp. & Valvatida: Asterinidae & 2 & inner chamber at about $50 \mathrm{~m}$ depth \\
\hline $\begin{array}{l}\text { Nerita plicata Linnaeus, } \\
1758\end{array}$ & Cycloneritomorpha: Neritidae & 1 & $\begin{array}{l}\text { River bank; Benthic surfaces and } \\
\text { above watermark }\end{array}$ \\
\hline $\begin{array}{l}\text { Nerita squamulata Le } \\
\text { Guillou, } 1841\end{array}$ & Cycloneritomorpha: Neritidae & 5 & $\begin{array}{l}\text { River bank; Benthic surfaces and } \\
\text { above watermark }\end{array}$ \\
\hline $\begin{array}{l}\text { Nerita insculpta Récluz, } \\
1841\end{array}$ & Cycloneritomorpha: Neritidae & 5 & $\begin{array}{l}\text { River bank; Benthic surfaces and } \\
\text { above watermark }\end{array}$ \\
\hline $\begin{array}{l}\text { Neritina turrita } \\
\text { (Gmelin, 1791) }\end{array}$ & Cycloneritomorpha: Neritidae & 2 & $\begin{array}{l}\text { River bank; Benthic surfaces and } \\
\text { above watermark }\end{array}$ \\
\hline $\begin{array}{l}\text { Neritina gagates } \\
\text { Lamarck, } 1822\end{array}$ & Cycloneritomorpha: Neritidae & 3 & $\begin{array}{l}\text { River bank; Benthic surfaces and } \\
\text { above watermark }\end{array}$ \\
\hline $\begin{array}{l}\text { Neritina smithii W. } \\
\text { Wood, } 1828\end{array}$ & Cycloneritomorpha: Neritidae & 1 & $\begin{array}{l}\text { River bank; Benthic surfaces and } \\
\text { above watermark }\end{array}$ \\
\hline $\begin{array}{l}\text { Terebralia sulcata (Born, } \\
1778 \text { ) }\end{array}$ & $\begin{array}{l}\text { Coenogastropoda: } \\
\text { Potamididae }\end{array}$ & 3 & $\begin{array}{l}\text { River bank; Benthic surfaces and } \\
\text { above watermark }\end{array}$ \\
\hline $\begin{array}{l}\text { Littoraria scabra } \\
\text { (Linnaeus, 1758) }\end{array}$ & Littorinimorpha: Littorinidae & 7 & $\begin{array}{l}\text { River bank; Benthic surfaces and } \\
\text { above watermark }\end{array}$ \\
\hline $\begin{array}{l}\text { Metopograpsus cf. } \\
\text { oceanicus (Hombron \& } \\
\text { Jacquinot, 1846) }\end{array}$ & Decapoda: Grapsidae & 1 & $\begin{array}{l}\text { River bank; Benthic surfaces and } \\
\text { above watermark }\end{array}$ \\
\hline Parasesarma sp. & Decapoda: Sesarmidae & 7 & $\begin{array}{l}\text { River bank; Benthic surfaces and } \\
\text { above watermark }\end{array}$ \\
\hline $\begin{array}{l}\text { Coenobita Latreille, } \\
1829\end{array}$ & Decapoda: Coenobitidae & 1 & human trail \\
\hline Isognomon sp. & Pterioida: Isognomonidae & 3 & $\begin{array}{l}\text { River bank; Benthic surfaces and } \\
\text { above watermark }\end{array}$ \\
\hline $\begin{array}{l}\text { Brachidontes variabilis } \\
\text { (Krauss, 1848) }\end{array}$ & Mytiloida: Mytilidae & 2 & $\begin{array}{l}\text { River bank; Benthic surfaces and } \\
\text { above watermark }\end{array}$ \\
\hline $\begin{array}{l}\text { Pomacentrus Lacepède, } \\
1802\end{array}$ & Perciformes: Pomacentridae & 2 & H.E.R. swim area (by "panggal") \\
\hline
\end{tabular}

Representative macrofauna species totaling forty-three (43) individuals found along the riverbank and "swimming area" were also collected. Eight (8) species of gastropods belonging to the family Neritidae, Potamididae and Littorinidae and two bivalve species belonging to the family Mytilidae and Pteriidae were identified. All the gastropods collected are marine species except for Neritina turrita, Neritina gagartes (considered as freshwater to brackish water inhabitants) and Neritina smithii (a strictly freshwater species). Meanwhile, three species of decapod crustaceans (belonging to the Families Grapsidae, Sesarmidae and Coenobitidae) were also sampled from the study area. A single species of damselfish, Pomacentrus sp. was caught within the "swimming area" with the fish trap. Noteworthy though are the numerous economically-important marine fishes (many are mature by size estimates) noted in the river (Table 3). A species of terrestrial hermit crab, Coenobita sp. was spotted within the tourist trail by the riverbank. 
Table 3. Listing of fish species sighted in the Hinatuan Enchanted River System.

\begin{tabular}{ll}
\hline Species & Taxonomic Group (Family) \\
\hline Rhinecanthus aculeatus (Linnaeus, 1758) & Balistidae \\
Balistoides viridescens (Bloch \& Schneider, 1801) & Balistidae \\
Scatophagus argus (Linnaeus, 1766) & Scatophagidae \\
Lutjanus fulvus (Forster, 1801) & Lutjanidae \\
Lutjanus fulviflamma (Forsskål, 1775) & Lutjanidae \\
Lutjanus sp. 1 & Lutjanidae \\
Lutjanus sp. 2 & Lutjanidae \\
Naso vlamingii (Valenciennes, 1835) - juvenile & Acanthuridae \\
Acanthurus nigricauda Duncker \& Mohr, 1929 & Acanthuridae \\
Acanthurus triostegus (Linnaeus, 1758) & Acanthuridae \\
Siganus vermiculatus (Valenciennes, 1835) & Siganidae \\
Siganus guttatus (Bloch, 1787) & Siganidae \\
Sphaeramia nematoptera (Bleeker, 1856) & Apogonidae \\
Letbrinus harak (Forsskål, 1775) & Lethrinidae \\
Lethrinus sp. & Lethrinidae \\
Arothron sp. & Tetraodontidae \\
Epinephelus sp. & Serranidae \\
Monodactylus argenteus (Linnaeus, 1758) & Monodactylidae \\
Goby 1 & Gobiidae \\
\hline
\end{tabular}

The Hinatuan Enchanted River is currently used by local residents as well as foreign and local tourists mainly for recreation. It is instructive to note that phosphate concentrations inside underwater caves, in general, are usually very low $(0.10 \mathrm{mg} / \mathrm{L})$ and high amounts can indicate some form of nutrient enrichment (Poulson, 1991). The higher concentration of phosphate in the upstream and midstream stations suggest allochthonous (i.e., agriculture) input from adjacent habitats. While it's tempting to correlate this to past anecdotal observations by the locals of the upstream and midstream becoming greenish, thus, suggesting the occurrence of an algal bloom, but this cannot be verified yet for lack of sufficient scientific data obtained for this survey. The low turbidity noted inside HERUCS and its connecting river can be attributed to strong discharge of freshwater from the spring as well as the bidirectional flow of tidally-induced seawater. Coincidentally, the total coliform counts of water samples taken in the upstream station (part of the designated swimming area) were relatively higher. It is highly advisable that more specific analysis be taken to determine if the coliform detected in the water are of fecal origin or not. The total organic matter (TOM) content of surface sediments from inside HERUCS (i.e., 2.2 to 11.0 percent) was low suggesting limited allochtonous input of POM from the cave's freshwater outflow especially during low tide.

Ecologically, aquatic cave animals can be subdivided into stygobites (caveadapted species restricted to subterranean waters), stygophiles (species inhabiting caves and completing their entire life cycle there, but which also occur in similar open water habitats), stygoxenes (species common in caves, but which must leave the cave to feed or reproduce) and accidentals (species that are washed into caves, but which cannot survive there for very long) (Iliffe, 2008).

The presence of accidentals within HERUCS can be explained by its connection with adjacent habitats brought by the strong and reversing tidal water currents. Species like the upside-down jellyfish, Cassiopeia andromeda and the 
asterinid, Aquilonastra burtoni are examples of organisms that are brought into the cave and may not survive very long. C. andromeda possesses photosynthetic zooxanthellae in its tentacles that need sunlight to be able to manufacture food for both itself and the scyphozoan. On the other hand, two possible species of the bivalve Isognomon (Pteriidae) were found inside HERUCS. Isognomon ephippium was collected in the middle and inner chamber at a depth ranging from 39 to 48 meters while a possible second species of Isognomon (still to be verified) was collected at the inner chamber (50 $\mathrm{m}$ depth). These filter-feeding bivalves are highly selective of the substrates to attach to. Isognomon species usually prefer crevices as a refuge from predators and more extreme physical factors ensuring higher survival of recruits in these microhabitats (Zamprogno et al., 2010). I. ephippium is considered to be an indicator of spatio-temporal environmental variables in tropical coastal ecosystems (Lazareth et al., 2003). Both are originally classified as inhabitants of shallow coasts and their occurrence inside HERUCS showed their capability of living in a different type of environment than its natural, well-lit habitat. These bivalves may have thrived on detritus and organic matter in the water column that are brought into the subterranean environment during the changing of the tides. As such, these Isognomon species inside HERUCS could be classified as stygophiles (sensu Welbourn, 1999). Still, there is a need for additional data to verify such observation and to warrant their classification.

Additionally, the strong tidal influence brought common marine intertidal inhabitants further upstream into the Hinatuan Enchanted River. Among these are several species of neritids such as Nerita plicata, a species capable of tolerating desiccation and strong wave action, and are frequently found in the upper limits of the intertidal zone (Ruwa and Jaccarini, 1986). The collection of sedentary Isognomon, a marine species that form dense colonies in tropical shallow waters, along the riverbanks is another evidence of the influence of seawater influx. The mussel, Brachidontes variabilis, a known bio-indicator (Nakhle et al., 2006) in coastal waters, was found in benthic surfaces of the river bank (just above the watermark). The presence of mangrove vegetation in the midstream and downstream areas of the river may explain the occurrence of mangrove-associated crabs, Metopograpsus cf. oceanicus and Parasesarma sp. in the study area. Sesarmid crabs are considered to be one of the most diverse and important faunal components of mangrove communities through their roles in leaf turnover (Guerao et al., 2004). The terrestrial hermit crab, Coenobita sp., sighted from the human trail could be a common inhabitant in the area. These land crabs represent an excellent opportunity to investigate the effects of the transition from sea to land (Krang et al., 2012).

\section{CONCLUSION AND RECOMMENDATIONS}

In a predominantly karstic geography, caves are interesting and yet, are the least studied features in the Philippines. Caves are extremely unique ecosystems that can host a distinct group of organisms but are very vulnerable to anthropogenic activities. "Wet" caves in particular, are more sensitive to disturbance as localized water input makes them more exposed to pollutants (Poulson, 1976). Hence, conservation efforts are necessary. Protection of caves should not only involve those in the subterranean environment but also the 
surrounding areas. The amount of detritus and organic matter that enter these systems will ultimately depend on what is found outside of the caves and hence, are equally important and worth conserving.

While the current water quality data obtained from this rapid survey may be insufficient to draw some conclusions, this can be used as reference for; (1) the future classification of this cave; (2) for detailed surveys and monitoring of HERUCS; and, (3) formulation of management and conservation initiatives as soon as possible.

Data show that organisms observed inside HERUCS are considered accidentals. However, the significance of this study rest on the idea that in the absence of any published records on species inventory around the HERUCS, the said organisms represent new records for the area. The possibility of discovering new species is very high and hence, further studies and explorations are highly recommended.

\section{ACKNOWLEDGEMENT}

The financial support of Deutsche Gesellschaft für Internationale Zusammenarbeit (GIZ) GmbH contract \# 83189337 under its Protected Area Management Enhancement in the Philippines (PAME-PH) Project is hereby acknowledged. We thank the Biodiversity Management Bureau (BMB) of the Department of Environment and Natural Resources (DENR) and the local government unit of Hinatuan, Surigao del Sur for providing logistical support during the survey. Aside from co-authors AS and BG, the following Filipino Cave Divers: Jaime Lapac, Juan Naval, Ferdinand Edralin, Jake Miranda and Lyndon Cubillan, participated in the underwater cave diving and specimen collection. The survey was covered under DENR Gratuitous Permit \# R13-2015-001. The logistics support extended by the Office of Research, University of San Carlos is hereby acknowledged.

\section{REFERENCES}

APHA. 1989. Standard Methods for the Examination of Water and Wastewater. 17th edition, American Public Health Association, Washington D.C., 1,268 pp.

ARGENTE, F.A.T., H.P. PALLA, C.I. NARIDO, M.A. CELEDONIO, and D.T. DY. 2013. The distribution and concentration of organic matter in the surface sediments of Calape Bay, Bohol, Central Philippines. Philippine Journal of Science. $142(2): 33-141$.

CHEVALDONNÉ, P. and C. LEJEUSENE. 2003. Regional warming-induced species shift in north-west Mediterranean marine caves. Ecology Letters. 6:371-379.

CULVER, D.C., L.L. MASTER, and H.H. HOBBS. 2000. Obligate cave fauna of the 48 contiguous United States. Conservation Biology. 14: 386-401.

GUERAO, G., K. ANGER, U.W.E. NETTLEMANN, and C.D. SCHUBART. 2004. Complete larval and early juvenile development of the mangrove crab Pariesesarma fasciatum (Crustacea: Brachyura: Sesarmidae) from Singapore, with arval comparison of Parasesarma and Perisesarma. Journal of Plankton Research. 25(12) 1389-1408. 
GUIDO, A., A. MANTASDREA, A. ROSSO, R. SANFILIPPO, F. TOSTI, R. RIDING and F. RUSSO. 2014. Commensal symbiosis between agglutinated polychaetes and sulfate reducing bacteria. Geobiology. 12(3). 265-275.

ILIFFE, T. 2008. Biology of underwater caves. Jill Heinerth and Bill Oigarden (eds.): Cave Diving, Articles \& Opinions, Heinerth Productions, High Springs, FL. 63-68.

JANAKA, G.H.A., J. KUMARA, K. HAYANO, and K. OGIWARA. 2012. Image Analysis Techniques on Evaluation of Particle Size Distribution of Gravel. International Journal of Geomate. 3(1):290-297.

KAMBESIS, P. 2007. The importance of cave exploration to scientific research. Journal of Cave and Karst Studies. 69(1): 46-58.

KNITTWIESS, L., P. CHEVALDONNE, A. ERESKOVSKY, P.J. SCHEMBRI, and J.A. BORG. 2015. Exploring a poorly known habitat in the Maltese Islands: a preliminary survey of some marine caves. Xjenza - in press.

KRANG, A., M.M. KNADEN, K. STECH, and B.S. HANSSON. 2012. Transition from sea to land: olfactory function and constraints in the terrestrial hermit crab, Coenobita cypeatus. Proceedings of the Royal Society B, 367(279): 3510-3519.

LAZARETH, C.E., E. VANDER PUT'TEN, L. ANDRE, and F. DEHAIRS. 2003. High-resolution trace element profiles in shells of the bivalve Isognomon ephippium; a record of environmental spatio-temporal variations? Estaurine, Coastal and Shelf Science. 57:1103-1114.

NAKHLE, K.F., D. COSSA, G. KHALAF and B. BALIAEFF. 2006. Brachidontes varibilis and Patella sp. as quantitative biological indicators for cadmium, lead and mercury in the Lebanese coastal waters. Environmental Pollution. 142(1):7382.

POULSON, T.L. 1976. Management of biological resources in caves. In: Proceedings of the National Cave Managemenl Symposium, Albuquerque. New Mexico. 1975. Albuquerque (NM): Speleobooks. 46-52.

POULSON, T.L. 1991. Assessing groundwater quality in caves using indices of biological integrity. Pages 495- 511 In: Proceedings of the third conference on hydrology, ecology, monitoring and management of groundwater in karst terrains. December 1991. Nashville, Tennessee.

RUWA, R., and V. JACCARINI. 1986. Dynamic zonation of Nerita plicata, N. undata and N. textilis (Prosobranchia:Neritacea) population on a rocky shore in Kenya. Marine Biology. 92: 425-430.

SAGEMAN, B. B., P.B. WIGNALL, and E.G. KAUFFMANN. 1999. Biofacies model on oxygen-deificient facies in epicontinental seas: tool for paleoenvironmental analysis. In Cycles and Events Stratigraphy (eds Einsele G, Ricken W, Seilacher A). Springer, Berlin. 542-564.

SMALL, C. and R.J. NICHOLLS. 2003. A global analysis of human settlement in coastal zones. Journal of Coastal Research. 19:584-599.

WELBOURN, W.C. 1999. Invertebrate cave fauna of Kartchner Caverns, Arizona. Journal of Caves and Karst Studies. 61(2): 93-101.

WYNNE, J.J. and W. PLEYTEZ. 2005. Sensitive ecological areas and species inventory of Actun Chapat Cave, Vaca Plateau, Belize. Journal of Cave and Karst Studies. 3: 148-157. 
ZAMPROGNO, G.C., L.L. FERNANDEZ, and F. DA COSTA FERNANDES. 2010. Spatial variability in the population of Isognomon bicolor (C.B. Adams, 1845)(Mollusca, Bivalvia) on rocky shores in Espirito Santo, Brazil. Brazilian Journal of Oceanography. 58(1):23-29. 